\title{
Pengaruh Minat Belajar Siswa Terhadap Hasil Belajar Siswa di Madrasah Ibtidaiyah Darussalam Sungai Salak Kecamatan Tempuling
}

\author{
Aprijal $^{1}$, Alfian $^{2}$ Syarifudin $^{3}$ \\ ${ }^{1}$ Pendidikan Guru Madrasah Ibtidaiyah, STAI Auliaurrasyidin, Tembilahan Riau, Indonesia \\ ${ }^{2}$ Pendidikan Guru Madrasah Ibtidaiyah, STAI Auliaurrasyidin, Tembilahan Riau, Indonesia \\ ${ }^{3}$ Pendidikan Guru Madrasah Ibtidaiyah, STAI Auliaurrasyidin, Tembilahan Riau, Indonesia \\ *Corresponding author: aprijal@gmail.com \\ *Corresponding author: alfian@gmail.com \\ *Corresponding author: syarifmp3@gmail.com
}

\begin{abstract}
Abstrak
Minat belajar siswa adalah kecenderungan atau keinginan yang besar terhadap aktivitas untuk memperoleh pengetahuan dan peningkatan keterampilan dalam proses belajar. Hasil belajar siswa adalah perubahan yang terjadi setelah mengikuti suatu proses pembelajaran baik berupa nilai ataupun tingkah laku. Tujuan penelitian ini adalah untuk mengetahui pengaruh minat belajar siswa terhadap hasil belajar siswa pada mata pelajaran Akidah Akhlak di Madrasah Ibtidaiyah Darussalam Sungai Salak Kecamatan Tempuling dan apa faktor yang mempengaruhi hasil belajar siswa di Madrasah Ibtidaiyah Darussalam Sungai Salak Kecamatan Tempuling. Subjek dalam penelitian ini adalah siswa/i di Madrasah Ibtidaiyah Darussalam Sungai Salak Kecamatan, sedangkan objek dalam penelitian ini adalah pengaruh minat belajar terhadap hasil belajar siswa pada mata pelajaran Akidah Akhlak. Penelitian ini dilakukan dengan menggunakan tehnik observasi dan dokumentasi. Data yang diperoleh dianalisa dengan Teknik Regresi Linier. Hasil penelitian ini menunjukan bahwa terdapat pengaruh yang signifikan antara minat belajar dan hasil belajar siswa hal ini terbukti dari hasil perhitungan regresi linier diperoleh hasil $f_{\text {hitung }}>f_{\text {tabel }}(28,15>4,49)$ pada taraf $5 \%$ dengan demikian $\mathrm{H}_{\mathrm{a}}$ diterima dan $\mathrm{H}_{\mathrm{o}}$ ditolak, artinya ada pengaruh yang signifikan dan positif antara minat belajar siswa dan hasil belajar siswa di Madrasah Ibtidaiyah Darussalam Sungai Salak Kecamatan Tempuling.
\end{abstract}

Kata Kunci: Minat Belajar, Hasil Belajar.

\section{PENDAHULUAN}

Pendidikan merupakan salah satu bagian yang sangat penting dalam kehidupan manusia. Sebab, melalui pendidikan akan terbentuk Sumber Daya Manusia (SDM) yang berkualitas. Pendidikan yang berkualitas dapat terlihat dan terukur dengan tercapainya beberapa indikator, diantaranya adalah keberhasilan siswa dalam belajar. Namun untuk mencapai indikator tersebut bukanlah mudah. Karena, keberhasilan belajar sangat dipengaruhi oleh banyak faktor, salah satunya adalah minat anak dalam belajar. 
Slameto mengatakan bahwa minat adalah suatu rasa lebih suka dan rasa ketertarikan pada suatu hal atau aktivitas, tanpa ada yang menyuruh ${ }^{1}$. Minat memiliki peranan yang sangat penting dalam kehidupan siswa dan mempunyai dampak yang besar terhadap sikap dan perilaku. Siswa yang berminat terhadap kegiatan pembelajaran akan berusaha lebih keras dibandingkan siswa yang kurang berminat dalam belajar. Kegiatan belajar memerlukan pemusatan perhatian agar apa yang dipelajari dapat dipahami. Untuk meningkatkan minat belajar siswa, proses pembelajaran dapat dilakukan dalam bentuk kegiatan, siswa bekerja dan mengalami apa yang ada di lingkungannya secara individu maupun berkelompok.

Minat belajar sangat besar pengaruhnya terhadap hasil belajar, karena apabila bahan pelajaran yang dipelajari tidak sesuai dengan minat, maka siswa tidak akan belajar dengan baik sebab tidak menarik baginya. Siswa akan malas belajar dan tidak akan mendapatkan kepuasan dari pelajaran itu. Bahan pelajaran yang menarik minat siswa, lebih mudah dipelajari sehingga dapat meningkatkan hasil belajar.

Menurut Djamarah pendidikan yang paling efektif untuk membangkitkan minat belajar pada siswa adalah dengan menggunakan minat-minat siswa yang telah ada, dan membentuk minat-minat baru pada diri siswa. ${ }^{2}$ Hal ini dapat dicapai dengan cara memberikan informasi pada siswa mengenai hubungan antara suatu bahan pengajaran yang akan diberikan dengan bahan pengajaran yang lalu, menguraikan kegunaan bagi siswa dimasa yang akan datang. Minat dapat dibangkitkan dengan cara menghubungkan materi pelajaran dengan suatu berita sensasional dan viral yang sudah diketahui kebanyakan siswa.

Minat belajar dalam diri siswa harus dipupuk secara terus menerus, sehingga akan semakin meningkat di dalam diri siswa. Namun, seiring dengan kemajuan teknologi yang semakin pesat dapat mengakibatkan dampak buruk pada minat belajar siswa. Banyak faktor yang dapat menurunkan minat belajar dalam diri siswa, seperti banyaknya jenis hiburan, game, dan tayangan TV yang dapat mengalihkan perhatian siswa dari buku pelajaran. Di samping itu banyaknya tempat hiburan yang menghabiskan waktu untuk belajar, seperti mall, karaoke, tempat rekreasi, dan play station.

Oleh sebab itu, guru dan orangtua sebaiknya membatasi waktu bermain siswa dan memberikan pengawasan yang ketat agar siswa mampu belajar dengan maksimal. Dengan minat belajar yang tinggi, siswa dapat memperoleh pengetahuan dan wawasan serta hasil belajar yang baik. Dalam pembelajaran guru harus melihat kondisi siswa, karena kondisi siswa sangat penting untuk diperhatikan. Kondisi siswa yang sangat penting adalah bagaimana minatnya dalam mata pelajaran. Siswa yang berminat akan lebih perhatian dan akan lebih ingin tahu terhadap mata pelajaran yang dipelajarinya.

Pengembangan minat dan kebiasaan belajar Akidah Akhlak yang baik, perlu ditumbuhkan dalam diri siswa sedini mungkin. Guru mempunyai peranan yang sangat hlm. 180 .

${ }^{1}$ Slamento, Belajar dan Faktor-faktor yang Mempengaruhinya, (Jakarta: Rineka Cipta, 2010),

${ }^{2}$ Saiful Bahri Djamarah, Strategi Belajar Mengajar, (Jakarta: Rineka Cipta, 2002), hlm. 158. 
penting, dalam usaha meningkatkan minat belajar siswa. Seperti yang dikemukakan oleh Djamarah bahwa dalam proses belajar, motivasi sangat diperlukan, sebab seseorang yang tidak mempunyai motivasi dalam belajar, tak akan mungkin melakukan aktivitas belajar. ${ }^{3}$ Minat bukan saja dapat mempengaruhi tingkah laku seseorang, tapi juga dapat mendorong orang untuk tetap melakukan sesuatu. Dalam hal ini minat merupakan landasan penting bagi seseorang, untuk melakukan dan memperoleh sesuatu.

Anak-anak malas, tidak belajar, gagal karena tidak ada minat. Dalam kegiatan belajar, minat mempunyai peranan yang sangat penting. Bila seorang siswa tidak memiliki minat dan perhatian yang besar terhadap objek yang dipelajari, maka sulit diharapkan siswa tersebut akan tekun dan memperoleh hasil yang baik dari belajarnya. Sebaliknya, apabila siswa tersebut belajar dengan minat dan perhatian besar terhadap objek yang dipelajari, maka hasil yang diperoleh lebih baik.

Minat berkaitan dengan motivasi, karena minat merupakan dorongan dalam diri seseorang atau faktor yang menimbulkan perhatian secara selektif, yang menyebabkan dipilihnya suatu objek atau kegiatan yang menguntungkan, menyenangkan yang lama kelamaan akan mendatangkan kepuasan. Oleh karena itu antara dorongan, perhatian dan rasa senang pada suatu kegiatan saling berkaitan dengan faktor yang menimbulkan minat. Apabila faktor-faktor yang menimbulkan minat pada suatu kegiatan rendah maka dapat menyebabkan minat orang tersebut rendah. Minat yang rendah dapat menimbulkan rasa bosan terhadap suatu kegiatan. Apabila ini terjadi pada minat belajar, maka akan berdampak pada kesulitan belajar orang tersebut. Dalam hal ini, minat belajar siswa sangat berpengaruh terhadap hasil belajar siswa.

Hasil belajar siswa adalah perubahan yang terjadi setelah mengikuti suatu proses pembelajaran, baik berupa nilai ataupun tingkah laku. Sejalan yang dikatakan oleh Purwanto, bahwa hasil belajar siswa adalah perubahan tingkah laku yang terjadi setelah mengikuti proses belajar mengajar sesuai dengan tujuan pendidikan. ${ }^{4}$

Selain itu, agar tujuan pembelajaran akidah akhlak di Madrasah Ibtidaiyah dapat tercapai seperti yang diharapkan, perlu diperhatikan faktor-faktor yang mempengaruhi proses belajar siswa. Menurut Slamento keberhasilan dalam belajar dipengaruhi oleh faktor eksternal sebagai faktor di luar diri siswa, misalnya metode belajar, kurikulum, serta sarana yang menunjang keberhasilan siswa dalam belajar. Sedangkan faktor internal adalah sebagai faktor-faktor dari dalam diri siswa yaitu kondisi fisik dan panca indera, serta faktor psikologi yaitu bakat, minat, kecerdasan, motivasi dan kemampuan kognitif. $^{5}$

Pembelajaran merupakan interaksi antara guru dengan siswa. Pembelajaran yang baik seharusnya dapat menumbuhkan minat belajar pada diri siswa, agar tingkah laku mereka berubah. Perubahan yang dimaksud yaitu perubahan aspek-aspek tingkah laku, seperti pengetahuan, sikap dan keterampilan. Begitu juga dalam pembelajaran Akidah Akhlak yang sangat menekankan pada perubahan aspek-aspek di atas. Tapi pada

\footnotetext{
${ }^{3}$ Ibid.., hlm. 160.

${ }^{4}$ Purwanto, Evaluasi Hasil Belajar, (Yogyakarta: Pustaka Pelajar, 2010), hlm. 54.

${ }^{5}$ Slamento, Op.Cit., hlm. 54.
} 
kenyataannya banyak guru dalam mengajar pelajaran Akidah Akhlak tidak mengikut sertakan keaktifan siswa baik secara fisik maupun mentalnya, dengan pengertian bahwa guru tidak melibatkan siswanya secara aktif.

Siswa hanya dibiarkan dengan kegiatan mereka masing-masing, sementara guru juga hanya memberikan ceramah kepada siswa tanpa peduli dengan kegiatan yang dilakukan oleh siswa. Pembelajaran yang terjadi sebaiknya bukan hanya pemberian informasi dari guru kepada siswa, tanpa mengembangkan gagasan kreatif siswa, melainkan melalui komunikasi timbal balik antara guru dengan siswa, siswa dapat terlibat aktif dalam belajar baik mental, intelektual, emosional maupun fisik agar mampu mencari dan menemukan pengetahuan, sikap, dan keterampilan.

Berdasarkan hasil pengamatan pada hari Senin-Kamis, Tanggal 20-23 April 2020 yang penulis lakukan di Sekolah Madrasah Ibtidaiyah Darussalam Sungai Salak Kecamatan Tempuling, peneliti menemukan beberapa anak yang tidak memiliki minat dalam belajar Akidah Akhlak, hal ini terletak dari gejala-gejala sebagai berikut:

1. Siswa hanya mendengarkan apa yang dijelaskan guru.

2. Siswa tidak memperhatikan saat guru menjelaskan pelajaran.

3. Siswa bermain saat diskusi kelompok.

4. Suasana kelas kurang kondusif dalam belajar akidah akhlak.

5. Siswa tidak mengerjakan Pekerjaan Rumah (PR) akidah akhlak di rumah.

6. Hasil belajar siswa rendah.

Dari gejala-gejala tersebut peneliti termotivasi untuk melakukan penelitian lebih lanjut, dengan mengajukan beberapa rumusan masalah. Pertama, apakah terdapat pengaruh yang signifikan antara minat belajar terhadap hasil belajar siswa di Madrasah Ibtidaiyah Darussalam Sungai Salak Kecamatan Tempuling? Kedua, apa saja faktor yang mempengaruhi hasil belajar siswa di Madrasah Ibtidaiyah Darussalam Sungai Salak Kecamatan Tempuling?. Sedangkan tujuan penelitian yang penulis lakukan adalah untuk mengetahui pengaruh minat belajar terhadap Hasil Belajar Di Madrasah Ibtidaiyah Darussalam Sungai Salak Kecamatan Tempuling serta mengetahui faktorfaktor yang mempengaruhinya.

Manfaat penelitian ini sangat dirasakan berbagai pihak, misalnya: Pihak sekolah, Kepala Sekolah dan Guru dapat memperoleh informasi akurat berkenaan dengan pengaruh minat belajar siswa terhadap hasil belajar siswa di Madrasah Ibtidaiyah Darussalam Sungai Salak Kecamatan Tempuling. Sehingga dapat lebih meningkatkannya menjadi lebih baik dikemudian hari. Sedangkan bagi siswa dapat memacu dan membenahi diri untuk memperoleh hasil belajar yang lebih berkualitas. Sementara bagi peneliti dan pembaca dapat memperoleh pengalaman, pengetahuan, dan wawasan yang lebih mendalam.

\section{METODE PENELITIAN}

Penelitian ini termasuk jenis penelitian kuantitatif dengan menjadikan Madrasah Ibtidaiyah Darussalam Sungai Salak Kecamatan Tempuling sebagai lokasi penelitian. Penelitian ini menghabiskan waktu selama tiga bulan berturut-turut, mulai Juli sampai dengan September 2014. Ada 18 orang siswa kelas tinggi (4, 5, 6) di Madrasah 
Ibtidaiyah Darussalam Sungai Salak Kecamatan Tempuling yang dijadikan sebagai subjek $^{6}$ dalam penelitian ini, sementara yang menjadi objek penelitian ini adalah minat belajar siswa dan hasil belajar Siswa Di Madrasah Ibtidaiyah Darussalam Sungai Salak Kecamatan Tempuling.

Populasi $i^{7}$ dalam penelitian ini adalah Siswa kelas tinggi $(4,5,6)$ di Madrasah Ibtidaiyah Darussalam Sungai Salak Kecamatan Tempuling yang berjumlah 18 siswa. Pada penelitian ini penulis tidak menggunakan sempel, karena jumlah siswa yang ada Di Madrasah Ibtidaiyah Darussalam Sungai Salak Kecamatan Tempuling jumlahnya kurang dari 100 orang sehingga dapat diteliti seluruhnya.

Dalam pengumpulan data yang diperlukan pada penelitian ini, penulis menggunakan dua teknik pengumpulan data. Pertama, Teknik Observasi, yaitu melakukan pengamatan secara langsung keobjek penelitian untuk melihat dari dekat kegiatan yang dilakukan. Dan yang diobservasi dalam penelitian ini adalah minat belajar siswa MI Darussalam Sungai Salak Kecamatan Tempuling. Kedua, Teknik Dokumentasi, yakni mencari data mengenai hal-hal atau variabel yang berupa catatan, traskrip, buku, surat kabar, majalah, notulen rapat, lengger, agenda dan sebagainya. ${ }^{8}$ Dokumen yang penulis ambil adalah profil sekolah, data guru, data siswa dan data nilai siswa.

Data yang sudah terkumpul dalam penelitian ini, penulis kualifikasikan ke dalam bentuk angka-angka. Sehingga data tersebut bersifat kuantitatif. Untuk selanjutnya dianalisa dan diinterpretasikan secara deskriptif. Pengolahan data ke dalam bentuk kualitatif ini dapat ditempuh dengan menggunakan rumus analisis Regresi, yaitu: ${ }^{9}$

Persamaan regresi dirumuskan: $\hat{Y}=\alpha+b X$

Dimana:

$\hat{\mathrm{Y}}=$ (baca y topi) subjek variabel terikat yang diproyeksikan.

$\mathrm{X}=$ variabel bebas yang mempunyai nilai tertentu untuk diprediksikan.

$\alpha=$ Nilai konstanta harga $\mathrm{Y}$ jika $\mathrm{X}=0$

$\mathrm{b}=$ Nilai arah sebagai penentu ramalan (prediksi) yang menunjukkan nilai peningkatan

(+) atau nilai penurunan (-) variabel Y.

$$
\begin{aligned}
& b=\frac{n \cdot \sum X Y-\sum X \cdot \sum Y}{n \cdot \sum X^{2}-\left(\sum X\right)^{2}} \\
& a=\frac{\sum Y-b \cdot \sum X}{n}
\end{aligned}
$$

Langkah-langkah menjawab Regresi Sederhana:

Langkah 1 Membuat Ha dan Ho dalam bentuk kalimat.

Langkah 2 Membuat Ha dan Ho dalam bentuk statistik.

${ }^{6}$ Subjek adalah orang atau individu atau kelompok dijadikan unit atau satuan yang diteliti. Sanafiah Faisal, Format-Format Penelitian Sosial, (Jakarta: Raja Grafindo Persada, 2007), hlm. 109.

${ }^{7}$ Populasi menurut Suharsimi Arikunto adalah keseluruhan subjek dalam penelitian. Suharsimi Arikunto, ProsedurPenelitianSuatuPendekatanPraktik, (Jakarta: PT RinekaCipta, 2006), hlm. 130.

${ }^{8}$ Ibid.

${ }^{9}$ Riduwan, Metode dan Teknik Menyusun Tesis, (Bandung: Alfabeta, 2004), hlm. 145-146. 
Langkah 3 Membuat tabel penolong untuk menghitung skala statistik.

Langkah 4 Memasukkan angka-angka dari tabel penolonng dengan rumus: ${ }^{10}$

$$
\begin{aligned}
& b=\frac{n \cdot \sum X Y-\sum X \cdot \sum Y}{n \cdot \sum X^{2}-\left(\sum X\right)^{2}} \\
& a=\frac{\sum Y-b \cdot \sum X}{n}
\end{aligned}
$$

Langkah 5 Mencari jumlah kuadrat Regresi (JKReg(a)) dengan rumus:

$$
(\operatorname{JKReg}(\mathrm{a}))=\frac{\left(\sum Y\right)^{2}}{n}
$$

Langkah 6 Mencari jumlah kuadrat Regresi (JKReg(b/a))dengan rumus:

$$
\operatorname{JKReg}(\mathrm{b} / \mathrm{a})=b \cdot\left\{\sum X Y-\frac{\left(\sum X \cdot \sum Y\right)}{n}\right\}
$$

Langkah 7 Mencari jumlah kuadrat Residu (JKRes) dengan rumus:

$$
J K \operatorname{Res}=\sum \mathrm{Y}^{2}-J K \operatorname{Reg}(\mathrm{b} / \mathrm{a})-J K \operatorname{Reg}(\mathrm{a})
$$

Langkah 8 Mencari rata-rata jumlah kuadrat Regresi(RJK $\left.\operatorname{Reg}_{\text {(a) }}\right)$ dengan rumus:

$$
\left(\mathbf{R J K}_{\operatorname{Reg}(\mathbf{a})}\right)=(\boldsymbol{J K R e g}(\mathbf{a}))
$$

Langkah 9 Mencari rata-rata jumlah kuadrat regresi $\left(\mathrm{RJK}_{\mathrm{Reg}(\mathrm{b} / \mathrm{a})}\right)$ dengan

$$
\text { rumus: }\left(\operatorname{RJK}_{\operatorname{Reg}(\mathbf{b} / \mathbf{a})}\right)=(\mathbf{J K R e g}(\mathbf{b} / \mathbf{a}))
$$

Langkah 10 Mencari rata-rata jumlah residu $\left(\mathrm{RJK}_{\mathrm{Res}}\right)$ dengan rumus:

$$
\text { hitung }(\mathrm{RJKRes})=\frac{(\mathrm{JKRes})}{n-2}
$$

Langkah 11 Menguji signifikansi dengan rumus: $\mathbf{F}_{\text {hitung }}=\frac{(\mathbf{R J K R e g}(\mathbf{b} / \mathbf{a}))}{(\mathbf{R J K R e s})}$

Kaidah pengujian signifikan:

Jika $F_{\text {hitung }} \geq F_{\text {tabel, }}$ maka tolak $\mathrm{H}_{\mathrm{o}}$ artinya signifikan dan

$\mathrm{F}_{\text {hitung }} \leq \mathrm{F}_{\text {tabel, }}$ terima $\mathrm{H}_{\mathrm{o}}$ artinya tidak signifikan ${ }^{11}$

Dengan taraf signifikan: $\alpha=0,01$ atau $\alpha=0,05$

Carilah nilai $\mathrm{F}_{\text {Tabel }}$ menggunakan Tabel $\mathrm{F}$ dengan rumus:

$\mathrm{F}_{\text {Tabel }}=\mathrm{F}_{\{(1-\alpha)(\mathrm{dk} \operatorname{Reg}(\mathrm{b} / \mathrm{a})\} .(\mathrm{dk} \operatorname{Res})\}}{ }^{12}$

\section{HASIL PENELITIAN}

Setelah peneliti melakukan penganalisaan data, diperoleh hasil analisa mengenai pengaruh minat terhadap hasil belajar pendidikan Akidah Akhlak siswa kelas IV, V dan VI di Madrasah Ibtidaiyah Darussalam Sungai Salak, Kecamatan Tempuling. Kategori baik tidaknya pengaruh minat terhadap hasil balajar siswa pada mata pelajaran Akidah Akhlak dapat dilihat dari penetapan persentase kategori.

${ }^{10}$ Riduwan, Belajar Mudah Penelitian Untuk Guru - Karyawan dan Peneliti Pemula, (Bandung: alfabeta, 2010), hlm. 148.

${ }^{11}$ Ibid.

${ }^{12}$ Riduwan , Op.cit. hlm.149. 
Tabel 1. Rekapitulasi data hasil observasi minat siswa di MI Darusslam Sungai Salak Kecamatan Tempuling

\begin{tabular}{|c|c|c|c|c|c|c|c|c|c|c|c|}
\hline \multirow{2}{*}{ No } & \multirow{2}{*}{ KODE } & \multicolumn{7}{|c|}{ Aspek Yang Diteliti } & \multirow{2}{*}{$\begin{array}{c}\text { Skor } \\
\text { total }\end{array}$} \\
\cline { 3 - 10 } & & $\mathbf{1}$ & $\mathbf{2}$ & $\mathbf{3}$ & $\mathbf{4}$ & $\mathbf{5}$ & $\mathbf{6}$ & $\mathbf{7}$ & $\mathbf{8}$ & $\mathbf{9}$ & 27 \\
\hline 1 & 001 & 5 & 4 & 2 & 3 & 3 & 2 & 4 & 2 & 2 & 27 \\
\hline 2 & 002 & 5 & 3 & 4 & 5 & 4 & 4 & 5 & 2 & 2 & 34 \\
\hline 3 & 003 & 5 & 1 & 2 & 3 & 2 & 1 & 2 & 2 & 2 & 20 \\
\hline 4 & 004 & 5 & 5 & 4 & 5 & 3 & 4 & 4 & 2 & 1 & 33 \\
\hline 5 & 005 & 5 & 3 & 3 & 5 & 4 & 3 & 4 & 3 & 2 & 32 \\
\hline 6 & 006 & 5 & 5 & 5 & 5 & 4 & 3 & 5 & 2 & 1 & 35 \\
\hline 7 & 007 & 2 & 5 & 4 & 3 & 2 & 3 & 2 & 2 & 1 & 24 \\
\hline 8 & 008 & 5 & 2 & 2 & 2 & 3 & 1 & 3 & 3 & 1 & 22 \\
\hline 9 & 009 & 5 & 5 & 4 & 5 & 5 & 2 & 5 & 5 & 2 & 38 \\
\hline 10 & 010 & 4 & 4 & 1 & 2 & 3 & 2 & 3 & 4 & 2 & 25 \\
\hline 11 & 011 & 2 & 3 & 2 & 5 & 4 & 3 & 3 & 3 & 1 & 26 \\
\hline 12 & 012 & 3 & 3 & 3 & 5 & 4 & 2 & 4 & 3 & 1 & 28 \\
\hline 13 & 013 & 5 & 5 & 4 & 5 & 4 & 2 & 4 & 2 & 3 & 34 \\
\hline 14 & 014 & 3 & 3 & 2 & 5 & 3 & 2 & 4 & 3 & 3 & 28 \\
\hline 15 & 015 & 5 & 5 & 3 & 5 & 2 & 2 & 4 & 2 & 2 & 30 \\
\hline 16 & 016 & 5 & 5 & 3 & 5 & 2 & 3 & 3 & 3 & 2 & 31 \\
\hline 17 & 017 & 3 & 5 & 5 & 4 & 1 & 3 & 5 & 2 & 2 & 30 \\
\hline 18 & 018 & 5 & 4 & 4 & 4 & 1 & 3 & 2 & 2 & 1 & 26 \\
\hline
\end{tabular}

Sumber Data: Penelitian 2016/2017

Dari hasil rekapitulasi, didapatkan hasil $\mathrm{F}$ sebesar 523, sedangkan nilai $\mathrm{N}$ didapatkan hasil:

$$
\begin{aligned}
& N=\text { item pertanyaan } X \text { skor tertinggi } X \text { responden } \\
& N=9 \times 5 \times 18 \\
& N=\mathbf{8 1 0}
\end{aligned}
$$

Persentase tentang minat siswa dapat dianalisis dengan menggunakan rumus:

$$
\mathbf{P}=\frac{\mathbf{F}}{\mathbf{N}} \mathbf{X} \mathbf{1 0 0 \%}
$$

Keterangan :

$\mathrm{P}=$ Prosentase $(\%)$

$\mathrm{F}=$ Jumlah Jawaban (Akumulasi alternatif jawaban) 
$\mathrm{N}=$ Jumlah Responden. ${ }^{13}$

Sehingga persentase minat siswa di Madrasah Ibtidaiyah Darusslam Sungai Salak Kecamatan Tempuling adalah:

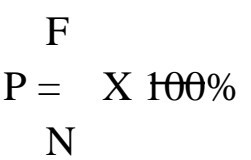

$$
\begin{aligned}
& \mathrm{P}=\frac{523}{810} \times 100 \% \\
& \mathrm{P}=\mathbf{6 4 , 5 7 \%}
\end{aligned}
$$

Jika dilihat dari persentase di atas dan disesuaikan dengan klasifikasi persentase, maka minat siswa di Madrasah Ibtidaiyah Darusslam Sungai Salak Kecamatan Tempuling dikategorikan "Baik", terlihat dari persentase sebesar 64,57\%.

Sedangkan rekapitulasi dari hasil belajar siswa yang dilihat dari hasil nilai ulangan harian siswa, sebagai berikut:

Tabel 2. Rekapitulasi Hasil Belajar Siswa Pada Mata Pelajaran Akidah Akhlak Kelas Tinggi $(4,5,6)$ di Madrasah Ibtidaiyah Darussalam Sungai Salak Kecamatan Tempuling

\begin{tabular}{|c|l|c|c|}
\hline Kode & \multicolumn{1}{|c|}{ Nama Siswa } & Kelas & Nilai \\
\hline 1 & Sopiala Diva & IV & 70 \\
\hline 2 & Nurhasana Hasanah & IV & 75 \\
\hline 3 & M. Riski & IV & 60 \\
\hline 4 & Rohati & IV & 80 \\
\hline 5 & Wahyu M & IV & 80 \\
\hline 6 & M. Aiman Al Azawahri & IV & 80 \\
\hline 7 & Samsul & IV & 70 \\
\hline 8 & Salrul & IV & 70 \\
\hline 9 & Nabila Nisovi & V & 90 \\
\hline 10 & Ahmad Jubaidi & V & 75 \\
\hline 11 & Ridwan & V & 70 \\
\hline 12 & Hukman Muntariq & V & 80 \\
\hline 13 & Mira Saputri & VI & 80 \\
\hline 14 & Nur Aminah & VI & 75 \\
\hline 15 & Nurhaliza & VI & 80 \\
\hline 16 & Sari Hamidah & VI & 75 \\
\hline 17 & Junaidi & VI & 70 \\
\hline 18 & Gus abdurrahmat & VI & 60 \\
\hline
\end{tabular}

${ }^{13}$ Anas Sudijono, Pengantar Statistik, (Jakarta: Raja Grafindo Persada, 2009), hlm. 43. 
KKM: 70

Sumber Data: Penelitian 2016/2017

Setelah diperoleh klasifikasi data tentang minat belajar (variabel X), dan hasil belajar (variabel Y). Selanjutnya dilakukan pengujian hipotesis dengan cara menganalisis data tersebut, dapat dilakukan dengan terlebih dahulu memasukkan data yang diperoleh ke dalam tabel penolong statistik sebagai berikut:

Tabel 3. Penolong Statistik

\begin{tabular}{|c|c|c|c|c|}
\hline $\mathrm{X}$ & $\mathrm{Y}$ & $\mathrm{X}^{2}$ & $\mathrm{Y}^{2}$ & $\mathrm{X} . \mathrm{Y}$ \\
\hline 27 & 70 & 729 & 4900 & 1890 \\
\hline 34 & 75 & 1156 & 5625 & 2550 \\
\hline 20 & 60 & 400 & 3600 & 1200 \\
\hline 33 & 80 & 1089 & 6400 & 2640 \\
\hline 32 & 80 & 1024 & 6400 & 2560 \\
\hline 35 & 80 & 1225 & 6400 & 2800 \\
\hline 24 & 70 & 576 & 4900 & 1680 \\
\hline 22 & 70 & 484 & 4900 & 1540 \\
\hline 38 & 90 & 1444 & 8100 & 3420 \\
\hline 25 & 75 & 625 & 5625 & 1875 \\
\hline 26 & 70 & 676 & 4900 & 1820 \\
\hline 28 & 80 & 784 & 6400 & 2240 \\
\hline 34 & 80 & 1156 & 6400 & 2720 \\
\hline 28 & 75 & 784 & 5625 & 2100 \\
\hline 30 & 80 & 900 & 6400 & 2400 \\
\hline 31 & 75 & 961 & 5625 & 2325 \\
\hline 30 & 70 & 961 & 4900 & 2100 \\
\hline 26 & 60 & 676 & 3600 & 1560 \\
\hline$\sum \mathrm{X}=523$ & $\sum \mathrm{Y}=1340$ & $\sum \mathrm{X}^{2}=15650$ & $\sum \mathrm{Y}^{2}=100700$ & $\sum \mathrm{X} . \mathrm{Y}=39420$ \\
\hline
\end{tabular}

Keterangan:

$\mathrm{N} \quad=$ Jumlah populasi atau sampel

$\Sigma$ X.Y $\quad=$ Jumlah hasil perkalian antara variabel $\mathrm{X}$ dan $\mathrm{Y}$

$\Sigma X \quad=$ Jumlah seluruh nilai $\mathrm{X}$

$\Sigma \mathrm{Y} \quad=$ Jumlah seluruh nilai $\mathrm{Y}$

$\sum X^{2} \quad=$ Jumlah kuadrat nilai $X$

$\sum \mathrm{Y}^{2} \quad=$ Jumlah kuadrat nilai $\mathrm{Y}$

1. Nilai "b", yaitu :

$b=\frac{n \cdot \sum X Y-\sum X \cdot \sum Y}{n \cdot \sum X^{2}-\left(\sum X\right)^{2}}$ 


$$
\begin{aligned}
b=\frac{18.39420-523.1340}{18.15589-(523)^{2}} & \\
= & \frac{709560-700820}{280602-273529}=\frac{8740}{7073}=1,24
\end{aligned}
$$

2. Jumlah Kuadrat Regresi ( $\left.\mathrm{JK}_{\text {reg }}[\mathrm{a}]\right)$, yaitu :

$$
\begin{aligned}
& \mathrm{Jk}_{\mathrm{reg}}(\mathrm{a})=\frac{\left(\sum Y\right)^{2}}{n} \\
& =\frac{(1340)^{2}}{18}=\frac{1795600}{18}=99755,56
\end{aligned}
$$

3. Jumlah Kuadrat Regresi $\left(\mathrm{JK}_{\mathrm{reg}}[\mathrm{b} / \mathrm{a}]\right)$, yaitu:

$$
\begin{aligned}
& \mathrm{JK}_{\text {reg }}(\mathrm{b} / \mathrm{a})=b \cdot\left\{\sum X Y-\frac{\left(\sum X\right) \cdot\left(\sum Y\right)}{n}\right\} \\
& \begin{aligned}
=1,24\left\{39420-\frac{523 \cdot 1340}{18}\right\} & \\
=1,24(39420-38934,44) & \\
= & 1,24(485,56) \\
= & 602,09
\end{aligned}
\end{aligned}
$$

4. Jumlah Kuadrat Residu (JKRes), yaitu:

$$
\begin{aligned}
& \mathrm{JK}_{\text {Res }}=\sum Y^{2}-\mathrm{JK}_{\text {Reg }}(\mathrm{b} / \mathrm{a})-\mathrm{JK}_{\text {Reg }}(\mathrm{a}) \\
= & 100700-602,09-99755,56 \\
= & 342,35
\end{aligned}
$$

5. Rata-rata Jumlah Kuadrat Regresi $\left(\mathrm{RJK}_{\mathrm{reg}}[\mathrm{a}]\right)$, yaitu:

$$
\mathrm{RJK}_{\mathrm{reg}}[\mathrm{a}]=\mathrm{JK}_{\mathrm{reg}}[\mathrm{a}]=\text { 99755,56 }
$$

6. Rata-rata Jumlah Kuadrat Regresi $\left(\mathrm{RJK}_{\mathrm{reg}}[\mathrm{b} / \mathrm{a}]\right)$, yaitu:

$$
\mathrm{RJK}_{\text {reg }}[\mathrm{b} / \mathrm{a}]=\mathrm{JKreg}[\mathrm{b} / \mathrm{a}]=602,09
$$

7. Rata-rata Jumlah Kuadrat Residu (RJKRes), yaitu:

$$
\begin{aligned}
& \mathrm{RJK}_{\mathrm{Res}}=\frac{\text { JKres }}{n-2} \\
& =\frac{342,35}{18-2}=21,39
\end{aligned}
$$

8. Menguji Signifikansi, yaitu:

$$
\begin{gathered}
F_{\text {hitung }}=\frac{R J K_{\operatorname{Re} g(b / a)}}{R J K_{\operatorname{Re} s}} \\
F_{\text {hitung }}=\frac{602,09}{21,39}=28,15
\end{gathered}
$$

9. Penentuan Nilai $F_{\text {tabel }}$ dengan taraf signifikansi $(\alpha)=0,05$ atau $5 \%$ yang dapat dicari dengan rumus:

Ftabel $=\{(1-0,05)(d k=3-2),(d k \operatorname{Res}=18-2)\}$ 


$$
\begin{array}{ll}
=\{(0,95) \cdot(1,16)\} \\
=F_{\text {tabel }}: \quad \text { Angka } 1=\text { Pembilang }\left(V_{1}\right) \\
& \text { Angka } 16=\text { Penyebut }\left(V_{2}\right)
\end{array}
$$

Setelah $F_{\text {hitung }}$ diperoleh selanjutnya dicari nilai $F_{\text {tabel }}$ pada tabel distribusi $F_{\text {tabel }}$ dengan cara mencari pada tabel $\mathrm{V}_{1}=1$ (Pembilang) dan $\mathrm{V}_{2}=41$ (Penyebut), maka diperoleh nilai $\mathrm{F}_{\text {tabel }}$ adalah 4,49 .

Dengan membandingkan nilai $\mathrm{F}_{\text {hitung }}$ dengan $\mathrm{F}_{\text {tabel}}$, maka terdapat selisih yang signifikan antara kedua nilai tersebut di mana $F_{\text {hitung }}(>)$ lebih besar dari $F_{\text {tabel, }}$ maka dalam penelitian ini Ho ditolak, dan ini berarti terdapat pengaruh yang signifikan antara minat terhadap hasil belajar siswa pada mata pelajaran Aqidah Akhlak di MI Darussalam sungai Salak Kecamatan Tempuling.

Berdasarkan data yang diperoleh dari teknik pengumpulan data observasi dan dokumentasi serta melalui tahapan analisis, maka diperoleh hasil $F_{\text {hitung }}$ adalah 28,15 sedangkan $F_{\text {tabel }}$ adalah 4,49. Jadi $F_{\text {hitung }}$ lebih besar $(>)$ dari $F_{\text {tabel }}$ berarti terdapat pengaruh yang signifikan dan positif.

Dari hasil analisis di atas, menggambarkan bahwa terdapat pengaruh yang signifikan dan positif antara minat siswa terhadap hasil belajar siswa pada mata pelajaran Aqidah Akhlak di MI Darussalam Sungai Salak Kecamatan Tempuling. Dengan demikian hipotesa yang diajukan pada bab terdahulu yakni, (Ho) terdapat pengaruh yang signifikan dan positif antara minat siswa terhadap hasil belajar siswa pada mata pelajaran Aqidah Akhlak di MI Darussalam Sungai Salak Kecamatan Tempuling.

Jika nilai $f_{\text {hitung }}>f_{\text {tabel }}$ atau $-t_{\text {hitung }}<-t_{\text {tabel }}$, maka Ho ditolak dan Ha diterima yang berarti signifikan.

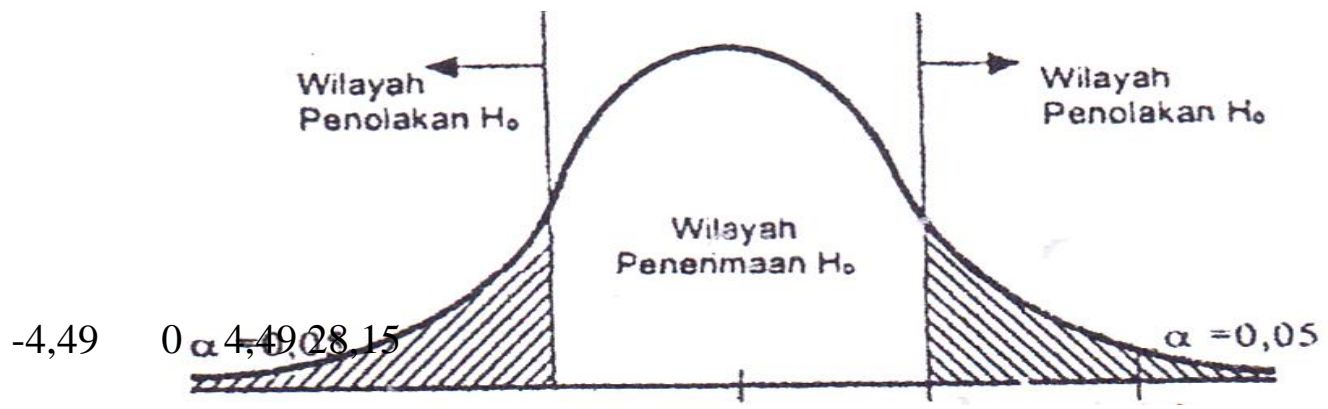

Karena f fitung berada didaerah penolakan, maka dalam penelitian ini Ho ditolak dan Ha diterima. Dengan demikian, dapat disimpulkan bahwa terdapat pengaruh yang signifikan.

Hasil penelitian menggambarkan bahwa terdapat pengaruh yang signifikan dan positif antara minat siswa terhadap hasil belajar siswa pada mata pelajaran Aqidah Akhlak di MI Darussalam Sungai Salak Kecamatan Tempuling. Dengan demikian hipotesa yang diajukan pada bab terdahulu yakni, $(\mathrm{H} \alpha)$ terdapat pengaruh yang signifikan dan positif antara minat siswa terhadap hasil belajar siswa pada mata pelajaran Aqidah Akhlak di MI Darussalam Sungai Salak Kecamatan Tempuling. 
Jika nilai $\mathrm{f}_{\text {hitung }}>\mathrm{f}_{\text {tabel }}$ atau $-\mathrm{t}_{\text {hitung }}<-\mathrm{t}_{\text {tabel}}$, maka Ho ditolak dan Ha diterima yang berarti signifikan.

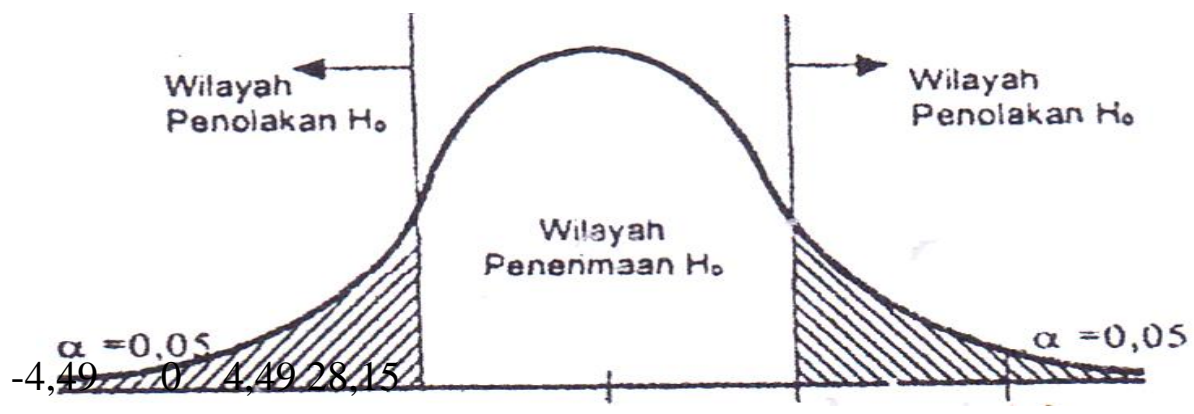

Karena $f_{\text {hitung }}$ berada didaerah penolakan, maka dalam penelitian ini Ho ditolak dan Ha diterima. Dengan demikian dapat disimpulkan bahwa terdapat pengaruh signifikan minat belajar dengan keberhasilan belajar siswa.

Berkaitan dengan di atas, menurut Muhibbin Syah minat itu tidak muncul dengan sendirinya akan tetapi banyak faktor yang dapat mempengaruhi munculnya minat. Ada beberapa faktor yang dapat mempengaruhi minat belajar siswa antara lain: Motivasi, Belajar, Bahan Pelajaran dan Sikap Guru, Keluarga, Teman Pergaulan, Lingkungan, Cita-cita, Bakat, Hobi, Media Massa, dan Fasilitas. ${ }^{14}$ Faktor-faktor tersebut di atas dapat dijelaskan sebagai berikut:

a. Motivasi

Dalam proses belajar, motivasi sangat diperlukan, sebab seseorang yang tidak mempunyai motivasi dalam belajar, tak akan mungkin melakukan aktivitas belajar. Menurut Mc.Donald dalam Djamarah motivasi adalah suatu perubahan energi di dalam pribadi seseorang yang ditandai dengan timbulnya afektif (perasaan) dan reaksi untuk mencapai tujuan ${ }^{15}$. Jika siswa mempunyai tujuan tertentu dari aktivitasnya, maka siswa tersebut mempunyai motivasi yang kuat untuk mencapainya dengan segala upaya yang dapat dia lakukan untuk mencapainya.

b. Belajar

Minat dapat diperoleh melalui belajar, karena dengan belajar siswa yang semula tidak menyenangi suatu pelajaran tertentu, lama kelamaan lantaran bertambahnya pengetahuan mengenai pelajaran tersebut, minat pun tumbuh sehingga ia akan lebih giat lagi mempelajari pelajaran tersebut. Seperti yang dikatakan Slameto belajar adalah

${ }^{14}$ Muhibbin Syah, Psikologi Belajar, (Jakarta: Raja Grapindo Persada, 2008), hlm. 157

${ }^{15}$ Saiful Bahri Djamarah, Strategi Belajar Mengajar, (Jakarta: Rineka Cipta, 2002), hlm. 148. 
suatu proses usaha yang dilakukan seseorang untuk memperoleh suatu perubahan tingkah laku yang baru secara keseluruhan, sebagai hasil pengalamannya sendiri dalam interaksi dengan lingkungannya ${ }^{16}$.

\section{c. Bahan Pelajaran dan Sikap Guru}

Faktor yang dapat membangkitkan dan merangsang minat adalah faktor bahan pelajaran yang akan diajarkan kepada siswa. Bahan pelajaran yang menarik minat siswa, akan sering dipelajari oleh siswa yang bersangkutan. Sebaliknya bahan pelajaran yang tidak menarik minat siswa tentu akan dikesampingkan oleh siswa.

Sebagaimana dikemukakan oleh Slameto bahwa Minat mempunyai pengaruh yang sangat besar terhadap belajar, karena bila bahan pelajaran yang dipelajari tidak sesuai dengan minat siswa, maka siswa tidak akan belajar dengan sebaik-baiknya, karena tidak ada daya tarik baginya ${ }^{17}$. Guru yang pandai, baik,ramah, disiplin, serta disenangi murid sangat besar pengaruhnya dalam membangkitkan minat murid. Sebaliknya guru yang memiliki sikap buruk dan tidak disukai oleh murid, akan sukar dapat merangsang timbulnya minat dan perhatian murid.

Bentuk-bentuk kepribadian gurulah yang dapat mempengaruhi timbulnya minat siswa. Oleh karena itu dalam proses belajar mengajar guru harus peka terhadap situasi kelas. Ia harus mengetahui dan memperhatikan akan metode-metode mengajar yang cocok dan sesuai dengan tingkatan kecerdasan para siswanya, artinya guru harus memahami kebutuhan dan perkembangan jiwa siswanya.

d. Keluarga

Orangtua adalah orang yang terdekat dalam keluarga, oleh karenanya keluarga sangat berpengaruh dalam menentukan minat seorang siswa terhadap pelajaran. Apa yang diberikan oleh keluarga sangat berpengaruh bagi perkembangan jiwa anak. Dalam proses perkembangan minat diperlukan dukungan perhatian dan bimbingan dari keluarga khususnya orangtua.

\section{e. Teman Pergaulan}

Melalui pergaulan seseorang akan dapat terpengaruh arah minatnya oleh temantemannya. Khusus bagi remaja, pengaruh teman ini sangat besar karena dalam pergaulan itulah mereka memupuk pribadi dan melakukan aktifitas bersama-sama untuk mengurangi ketegangan dan kegoncangan yang mereka alami.

\section{f. Lingkungan}

Melalui pergaulan seseorang akan terpengaruh minatnya. Minat dapat diperoleh dari sebagai dari pengalaman mereka dari lingkungan di mana mereka tinggal. Lingkungan sangat berperan dalam pertumbuhan dan perkembangan anak. Lingkungan adalah keluarga yang mengasuh dan membesarkan anak, sekolah tempat mendidik, masyarakat tempat bergaul, juga tempat bermain sehari-hari dengan keadaan alam dan iklimnya. Menurut Nana Sudjana besar kecilnya pengaruh lingkungan terhadap

${ }^{16}$ Slamento, Op.Cit., hlm.2.

${ }^{17}$ Ibid, hlm. 57 
pertumbuhan dan perkembangan, bergantung kepada keadaan lingkungan anak itu sendiri serta jasmani dan rohaninya ${ }^{18}$.

g. Cita-cita

Setiap manusia memiliki cita-cita di dalam hidupnya, termasuk para siswa. Citacita juga mempengaruhi minat belajar siswa, bahkan cita-cita juga dapat dikatakan sebagai perwujudan dari minat seseorang dalam prospek kehidupan di masa yang akan dating. Cita-cita ini senantiasa dikejar dan diperjuangkan, bahkan tidak jarang meskipun mendapat rintangan, seseorang tetap berusaha untuk mencapainya.

h. Bakat

Melalui bakat seseorang akan memiliki minat. Ini dapat dibuktikan dengan contoh: bila seseorang sejak kecil memiliki bakat menyanyi, secara tidak langsung ia akan memiliki minat dalam hal menyanyi. Jika ia dipaksakan untuk menyukai sesuatu yang lain, kemungkinan ia akan membencinya atau merupakan suatu beban bagi dirinya. Oleh karena itu, dalam memberikan pilihan baik sekolah maupun aktivitas lainnya sebaiknya disesuaikan dengan bakat dimiliki.

i. Hobi

Bagi setiap orang hobi merupakan salah satu hal yang menyebabkan timbulnya minat. Sebagai contoh, seseorang yang memiliki hobi terhadap matematika maka secara tidak langsung dalam dirinya timbul minat untuk menekuni ilmu matematika, begitupun dengan hobi yang lainnya. Dengan demikian, faktor hobi tidak bisa dipisahkan dari faktor minat.

j. Media Massa

Apa yang ditampilkan di media massa, baik media cetak ataupun media elektronik, dapat menarik dan merangsang khalayak untuk memperhatikan dan menirunya. Pengaruh tersebut menyangkut istilah, gaya hidup, nilai-nilai, dan juga perilaku sehari-hari. Minat khalayak dapat terarah pada apa yang dilihat, didengar, atau diperoleh dari media massa.

k. Fasilitas

Berbagai fasilitas berupa sarana dan prasarana, baik yang berada di rumah, di sekolah, dan di masyarakat memberikan pengaruh yang positif dan negatif. Sebagai contoh, bila fasilitas yang mendukung upaya pendidikan lengkap tersedia, maka timbul minat anak untuk menambah wawasannya. Tetapi apabila fasilitas yang ada justru mengikis minat pendidikannya, seperti merebaknya tempat-tempat hiburan yang ada di kota-kota besar, tentu hal ini berdampak negatif bagi pertumbuhan minat tersebut.

Faktor-faktor yang mempengaruhi hasil belajar

Setiap peserta didik memang tidak ada yang sama, perbedaan individual inilah yang menyebabkan perbedaan tingkah laku belajar dikalangan peserta didik. Sehingga menyebabkan perbedaan dalam hasil belajar. Hasil belajar merupakan hasil dari suatu

${ }^{18}$ Nana Sudjana, Penilaian Hasil Proses Belajar Mengajar, (Bandung: PT. Remaja Rosda Karya, 
proses, yang di dalamnya terdapat sejumlah faktor yang mempengaruhi tinggi rendahnya hasil belajar peserta didik tergantung pada faktor-faktor tersebut.

Menurut Muhibbin Syah, faktor-faktor yang mempengaruhi hasil belajar dibedakan menjadi 3 macam, yaitu:

a) Faktor internal (faktor dari dalam diri peserta didik), yakni keadaan/kondisi jasmani atau rohani peserta didik. Adapun yang tergolong faktor internal yaitu:

1) Faktor Fisiologis

Keadaan fisik yang sehat dan segar kuat akan menguntungkan dan memberikan hasil belajar yang baik. Tetapi keadan fisik yang kurang baik akan berpengaruh pada peserta didik dalam keadaan belajarnya.

2) Faktor Psikologis

Faktor psikologis yang dimaksud adalah adalah intelegensi, perahatian, minat dan bakat yang ada dalam diri peserta didik.

b) Faktor Eksternal (faktor dari luar peserta didik), yakni kondisi lingkungan sekitar peserta didik. Golongan faktor eksternal meliputi antara lain adalah:

1) Faktor Sosial, yang terdiri dari: lingkungan keluarga, lingungan sekolah, lingkungan masyarakat

2) Faktor Non Sosial, Faktor-faktor yang termasuk lingkungan non sosial adalah gedung sekolah dan letaknya, alat belajar, keadaan cuaca dan waktu belajar yang digunakan peserta didik. Faktor ini dipandang turut menentukan tingkat keberhasilan belajar peserta didik.

3) Faktor Pendekatan Belajar yakni jenis upaya belajar peserta didik yang meliputi strategi dan metode yang digunakan peserta didik untuk melakukan kegiatan pembelajaran materi-materi pelajaran. ${ }^{19}$

Uraian di atas dapat disimpulkan bahwa, hasil belajar peserta didik di sekolahnya sifatnya relatif, artinya dapat berubah setiap saat. Hal ini terjadi karena hasil belajar peserta didik sangat berhubungan dengan faktor yang mempengaruhinya, faktorfaktor tersebut saling berkaitan antara yang satu dengan yang lainya. Kelemahan salah satu faktor, akan dapat mempengaruhi keberhasilan seseorang dalam belajar. Dengan demikian, tinggi rendahnya hasil belajar yang dicapai peserta didik di sekolah didukung oleh faktor internal dan eksternal.

\section{KESIMPULAN}

Berdasarkan hasil penelitian yang telah penulis lakukan di Madrasah Ibtidaiyah Darussalam Sungai Salak Kecamatan Tempuling, dapat disimpulkan bahwa terdapat pengaruh yang signifikan antara minat belajar siswa dan hasil belajar siswa. Hal tersebut terbukti dari hasil perhitungan regresi linier, diperoleh hasil $f_{\text {hitung }}>f_{\text {tabel }}(28,15>$ 4,49) pada taraf 5\% dengan demikian $\mathrm{H}_{\mathrm{a}}$ diterima dan $\mathrm{H}_{\mathrm{o}}$ ditolak. Artinya ada pengaruh yang signifikan dan positif, antara minat belajar siswa dan hasil belajar siswa di

\footnotetext{
${ }^{19}$ Slameto, Op.Cit., hlm. 54-60.
} 
Madrasah Ibtidaiyah Darussalam Sungai Salak Kecamatan Tempuling, hal ini dipengaruhi oleh faktor sebagai berikut:

1. Pada saat proses belajar mengajar siswa dalam keadaan sehat.

2. Antusias siswa dalam proses belajar-mengajar yang baik.

3. Lingkungan keluarga siswa yang mendukung dan memberikan fasilitas seperti buku pelajaran, alat tulis, dll kepada siswa dalam belajar.

4. Lingkungan sekolah yang nyaman dan bersih untuk melakukan proses belajarmengajar.

5. Lingkungan masyarakat yang dapat menerima pendidikan dan mendukung agar terlaksananya pendidikan di sekolah.

6. Fasilitas sekolah yang layak dan baik, seperti buku pelajaran, bahan ajar, ruang kelas, meja/kursi, dan semua fasilitas yang mendukung dalam proses belajarmengajar.

7. Waktu yang digunakan dalam proses belajar-mengajar sudah memadai 70 menit dalam satu mata pelajaran. Guru sudah menggunakan metode dan strategi yang sesuai materi ajar.

Berdasarkan hasil penelitian di atas, dapat diberikan beberapa saran Kepada guru pada umumnya agar dapat memaksimalkan belajarnya dan siswa mendapatkan hasil belajar yang maksimal. Hendaknya guru tetap mendidik dan membimbing siswa agar selalu berakhlak yang baik sesuai dengan aturan yang ada, seperti halnya berbicara yang sopan, bertingah laku yang baik dimanapun kita berada. Saran yang penulis sampaikan kepada siswa-siswi adalah untuk lebih meningkatkan minat belajar dan rajin-rajinlah belajar, supaya mendapatkan hasil yang maksimal.

\section{DAFTAR PUSTAKA}

Arikunto, Suharsimi. 2006. Prosedur Penelitian Suatu Pendekatan Praktik. Jakarta: PT. Rineka Cipta.

Djamarah, Saiful Bahri. 2002. Strategi Belajar Mengajar, Jakarta: Rineka Cipta.

Faisal, Sanafiah. 2007. Format-Format Penelitian Sosial. Jakarta: Raja Grafindo Persada.

Purwanto. 2010. Evaluasi Hasil Belajar, Yogyakarta: Pustaka Pelajar.

Riduwan. 2004. Metode dan Teknik Menyusun Tesis. Bandung: Alfabeta. , 2010. Belajar Mudah Penelitian Untuk Guru - Karyawan dan Peneliti

Pemula. Bandung: Alfabeta.

Slamento. 2010. Belajar dan Faktor-faktor yang Mempengaruhinya. Jakarta: PT. Rineka Cipta.

Sudijono, Anas. 2009. Pengantar Statistik. Jakarta: Raja Grafindo Persada.

Sudjana, Nana. 2012. Penilaian Hasil Proses Belajar Mengajar. Bandung: PT. Remaja Rosda Karya.

Syah, Muhibbin. 2008. Psikologi Belajar. Jakarta: Raja Grafindo Persada. 